\title{
Kontribusi Metode Bermain Untuk Meningkatkan Aktivitas Belajar Dan Hasil Belajar Anak Sekolah Minggu
}

\author{
Christina Martha Wajabula*, I Nyoman Sudana Degeng, Dedi Kuswandi \\ Universitas Negeri Malang \\ Email: *christinmartha48@gmail.com
}

\begin{abstract}
This article aims to determine the contribution of the play method in improving learning activities and learning outcomes for Sunday School children at the Indria level. Based on the results of field observations, it is known that the activities and learning outcomes of children are not considered good criteria. This is because during the learning process at Sunday Schools, especially at the Indria Level, Sunday School Teachers still apply conventional teaching methods, so that children become bored and pay less attention to what is being taught. This study used a classroom action research method involving 20 children as the research sample. There are two cycles used with four stages starting from planning the action, implementing the action, observing the action and reflecting. The results showed that by applying the play method, children's learning activities increased and children's learning outcomes were also good.
\end{abstract}

Key Words: Playing Methods, Learning Activities, Learning Outcomes, Sunday School

\begin{abstract}
ABSTRAK: Artikel ini bertujuan untuk mengetahui adanya kontribusi dari metode bermain dalam meningkatkan aktivitas belajar dan hasil belajar anak Sekolah Minggu jenjang Indria. Berdasarkan hasil observasi di lapangan, diketahui bahwa aktivitas dan hasil belajar anak belum termasuk kriteria yang baik. Hal ini disebabkan pada saat proses pembelajaran di Sekolah Minggu khususnya di Jenjang Indria, Guru Sekolah Minggu masih menerapkan cara mengajar yang konvensional, sehingga anak menjadi bosan dan kurang memperhatikan apa yang diajarkan. Penelitian ini menggunakan metode penelitian Tindakan kelas yang melibatkan 20 anak sebagai sampel penelitian. Ada dua siklus yang digunakan dengan empat tahapan yang dimulai dari perencanaan tindakan, pelaksanaan tindakan, observasi tindakan dan refleksi. Hasil penelitian menunjukkan bahwa dengan menerapkan metode bermain, aktivitas belajar anak meningkat dan juga hasil belajar anak menjadi baik.
\end{abstract}

Kata Kunci: Metode Bermain, Aktivitas Belajar, Hasil Belajar, Sekolah Minggu

Article History: Submitted: 03 Oktober 2020

Revised: 23 Januari 2021

Accepted: 27 Januari 2021

\section{PENDAHULUAN}

Tahun 1780, Robert Raikes memperkenalkan Sekolah Minggu untuk pertama kalinya (Lie, 2009, pp. 110-111). Pelayanan, kehidupan, dan menjadi saksi gereja merupakan unsur yang komplet dari Sekolah Minggu sebagai Tubuh Kristus yang terlihat di dunia (Kristiono \& Perdana, 2019). Sekolah Minggu juga adalah salah satu bentuk ibadah anak (Panuntun, Tanduklangi, Adeng, \& Randalele, 2019), yang dilaksanakan setiap hari Minggu serta mempunyai tujuan untuk mengajarkan Alkitab dan nilai-nilai Kristen terhadap anak berumur 1-15 tahun (Darmawan \& Priskila, 2020). Kegiatan Sekolah Minggu ini dilak- sanakan sejak anak berusia 1 tahun agar mereka lebih memahami Alkitab dan nilai-nilai Kristiani secara mendalam. Di dalam kegiatan Sekolah Minggu, terjadi sebuah proses pembelajaran. Bernyanyi sama-sama, berdoa, membaca Alkitab serta mendengarkan cerita Alkitab merupakan aktivitas yang biasanya dilakukan (Mamangkey, Sinsuw, Karouw, \& Tuturoong, 2013).

Pada masa sekarang, Sekolah Minggu merupakan salah satu bentuk dari perhatian Gereja terhadap pendidikan anak yang diwujudkan dalam satu sistim pendidikan formal gereja (J. E. Rahael, 2013, p. 2). Kehadiran pendidikan formal gereja menan- 
dakan gereja terpanggil untuk berperan dalam menciptakan generasi muda gereja yang mampu bertanggungjawab terhadap dirinya dan untuk Tuhan Yesus Kristus selaku Kepala Gereja. Untuk menjawab panggilan itu, gereja melaksanakan perannya melalui kegiatan Sekolah Minggu. Sekolah Minggu akhirnya berkembang di berbagai tempat dan juga mulai masuk di wilayah Maluku (Luhulima, Degeng, \& Ulfa, 2018). Pelaksanaan pendidikan dan pembinaan bagi anak dan remaja GPM (Gereja Protestan Maluku) di Sekolah Minggu dibagi dalam beberapa kelompok: a) Anak Batita usia 1-3 tahun; b) Anak Indria dengan usia 4-6 tahun; c) Anak Kecil usia 7-9 tahun; d) Anak Tanggung 10-12 tahun, dan e) Anak Remaja berusia 13-15 tahun. Dalam penelitian ini, kelompok Sekolah Minggu yang dipilih yaitu pada kelas Anak Indria.

Sekolah Minggu yang bagus adalah Sekolah Minggu yang berpusat pada anak. Di tengah tantangan zaman semakin modern ini, Guru Sekolah Minggu diharuskan mampu menciptakan proses belajar dengan model yang bervariasi, metode dan media yang bisa memicu aktivitas belajar anak menjadi meningkat serta juga pembelajaran menjadi lebih menyenangkan. Dengan memakai peluang yang ada, Guru Sekolah Minggu dapat memberitakan firman Tuhan secara kreatif (Bayoe, Kouwagam, \& Tanyit, 2019).

Tugas mendidik, membina, dan mengajarkan nilai-nilai Kristiani pada anak Indria bukanlah hal yang mudah. Menurut Tinggi (2010), ada tiga hal yang harus diperhatikan dalam mengkomunikasikan Alkitab atau nilai-nilai Kristiani kepada anak, yaitu: (1) bermakna teologis; (2) efektif dalam mendidik; serta (3) sensitif terhadap perkembangan. Anak-anak pada usia ini adalah ciptaan Tuhan dan mereka juga perlu diajar. Dalam teori perkembangan kognitif Piaget, anak yang berusia 4 sampai 6 tahun termasuk dalam tahap pra-operasional (Ibda, 2015). Pada tahapan ini, anak sudah mulai memperlihatkan aktivitas kognitifnya ketika menemukan hal-hal yang berada di luar dirinya. Kegiatan berpikir belum terorganisir dengan baik tetapi dia sudah mulai memahami realitasi di lingkungan dengan menggunakan tanda-tanda, simbol serta gambar. Berdasarkan pemahaman dari Piaget inilah, untuk mencapai hasil seperti yang diharapkan pada tujuan pelajaran di Sekolah Minggu, metode dan kegiatan bagi anak-anak indria seharusnya lebih banyak melingkupi: metode cerita, doa, nyanyian drama, menunjukkan gambar, boneka, poster, permainan, percakapan, mendengarkan musik, ayat hafalan, kerajinan tangan, bermain dengan menggunakan benda alam, tanaman, batu, dan sebagainya (Djadi, 2007).

Penelitian yang dilakukan menerapkan metode bermain dalam proses pembelajaran di kelas Indria dengan memanfaatkan media permainan ular tangga. Montessori mendukung pernyataan ini yang dikutip dalam Sudono (2000, p. 2), pada saat anak bermain, segala sesuatu yang ada atau terjadi dalam lingkungan bermainnya, mereka akan menyerap dan mempelajari hal tersebut untuk pengetahuan mereka. Sehingga proses belajar mengajar itu dapat ditingkatkan melalui metode bermain. Usia ini juga merupakan usia yang tepat dalam membentuk kepribadian awal dan menambah pengetahuan rohaniah serta tumbuh kembang iman anak.

Secara umum metode mempunyai pengertian sebagai cara untuk mencapai tujuan. Metode juga salah satu elemen yang penting pada proses belajarmengajar, sebab dengan pemakaian metode yang baik dapat menumbuhkan aktivitas anak dalam belajar. Namun harus diakui bahwa proses pembelajaran yang terjadi di Sekolah Minggu Jemaat GPM Seri khususnya pada materi penciptaan belum terlalu baik. Hal ini bisa sepertinya disebabkan dengan pemakaian metode yang kurang kreatif dan juga kurangnya pembekalan untuk Guru Sekolah Minggu dalam melayani. Permasalahan seperti ini, menurut Kristiono dan Perdana yang dikutip oleh Riniwati (2020) dapat mempengaruhi pelayanan di Sekolah Minggu, sehingga aktivitas dan hasil belajar anak kurang memuaskan.

Aktivitas belajar adalah sebentuk proses kegiatan atau tindakan yang dilakukan seseorang untuk dapat membangun pengetahuannya serta keterampilan dalam diri masing-masing pada kegiatan pembelajaran. Pribadi (2009) dalam tulisannya, dia me- 
ngatakan bahwa kegiatan pembelajaran merupakan sebuah proses yang sengaja dirancang secara sistematik untuk mencapai hasil belajar efektif dan efisien. Apabila hal ini diserta dengan penggunaan metode dan media yang sesuai maka bisa menjadi kunci kesuksesan (Darmawan \& Kristanti, 2020). Jika dalam pengkajian yang dilakukan oleh Indrawati (2013) sebelumnya berbicara tentang peningkatan aktivitas dan hasil, maka dalam penelitian yang dilakukan oleh peneliti lebih menekankan kepada proses belajarmengajar di Sekolah Minggu Jemaat GPM Seri.

Berdasarkan latar belakang di atas, maka yang menjadi rumusan masalah dalam penelitian ini adalah apakah metode bermain dapat meningkatkan aktivitas belajar dan hasil belajar anak Sekolah Minggu jenjang Indria? Sedangkan yang menjadi tujuan yaitu untuk mengetahui kontribusi dari metode bermain terhadap peningkatan aktivitas dan hasil belajar anak indria.

\section{METODE}

Peneliti mendesain proses penelitian ini menggunakan metode Penelitian Tindakan Kelas (PTK). PTK berfokus pada kegiatan perbaikan yang dilakukan secara sistematis dan terencana supaya dapat mengatasi masalah pembelajaran yang dihadapi oleh Guru Sekolah Minggu. Hanifah dengan singkat menyebutkan bahwa PTK merupakan salah satu usaha memajukan proses dan hasil belajar anak (Hanifah, 2014, p. 1). Ebutt dalam Hanifah (2014, p. 2) juga mengatakan bahwa PTK adalah sebuah studi yang tertata dengan baik dan dilakukan supaya dapat memperbaiki praktik pendidikan ke arah yang lebih baik.

Peneliti melakukan penelitian dengan melibatkan 20 anak Sekolah Minggu jenjang Indria di Jemaat GPM Seri, Ambon-Maluku. Tahapan penelitian menggunakan siklus I dan II. Terdapat 4 tahapan pada setiap siklus, yaitu: 1) Perencanaan Tindakan; 2) Pelaksanaan Tindakan; 3) Observasi Tindakan; dan 4) Refleksi. Pengumpulan data dilakukan dengan menggunakan teknik observasi dan test hasil belajar.

Dalam proses kegiatan penelitian pada siklus I dilakukan dan disiapkan sebagai berikut: 1) Mem- buat rencana pelaksanaan pembelajaran; 2) Mempersiapkan papan permainan ular tangga sebagai media pembelajaran; 3) Merancang alat evaluasi untuk menilai penguasaan materi yang diajarkan; 4) membuat lembar observasi; 5) menggunakan instrument aktivitas belajar yang berupa checklist dan penilaian kriteria ya dan tidak.

Pada tahap pelaksanaan tindakan dilakukan dalam 2 putaran. Setiap siklus dilaksanakan pertemuan selama 30-45 menit. Anak yang hadir sejumlah 20 orang yang terdiri dari 12 anak perempuan dan 8 anak laki-laki. Dalam kegiatan ini, peneliti berperan sebagai guru Sekolah Minggu dengan membawakan materi "Penciptaan" di kedua siklus. Peneliti juga dibantu dengan 3 Guru Sekolah Minggu di jenjang Indria untuk membantu proses pembelajaran ini. Pelaksanaan proses pembelajaran di Sekolah Minggu dilakukan dalam 3 tahap yaitu: kegiatan awal, kegiatan inti, dan kegiatan akhir.

\section{HASIL DAN PEMBAHASAN}

\section{Hasil Penelitian}

Ada dua hasil penelitian yang dapat dijelaskan, yaitu: 1) Peningkatan aktivitas belajar anak dengan menggunakan metode bermain; dan 2) Metode bermain meningkatkan hasil belajar.

\section{Peningkatkan Aktivitas Belajar Anak dengan Menggunakan Metode Bermain}

Terjadi peningkatan aktivitas belajar dari siklus I ke II ketika anak menggunakan metode bermain. Hal ini dapat dilihat pada lima aspek yaitu: 1) anak dapat mengerti kegiatan pembelajaran dengan menggunakan metode bermain; 2) anak lebih bersemangat dalam belajar ketika menggunakan metode bermain; 3) anak tidak bosan dengan proses belajar mengajar; 4) anak menyukai cara belajar dengan metode bermain; dan 5) anak lebih memperhatikan Guru Sekolah Minggu ketika proses belajar. Rekapitulasi aktivitas belajar anak dapat ditunjukkan pada tabel Rekapitulasi Aktivitas Belajar anak berikut. 


\begin{tabular}{|c|l|c|c|c|c|}
\hline \multirow{2}{*}{ No } & \multicolumn{1}{|c|}{ Aspek yang di amati } & \multicolumn{3}{|c|}{ Proses Pembelajaran } \\
\cline { 3 - 5 } & \multicolumn{1}{|c|}{ Siklus I } & \multicolumn{2}{|c|}{ Siklus II } \\
\cline { 3 - 6 } 1 & $\begin{array}{l}\text { Anak dapat mengerti kegiatan PBM dengan menggunakan metode } \\
\text { bermain }\end{array}$ & 13 & $65 \%$ & 20 & $100 \%$ \\
\hline 2 & $\begin{array}{l}\text { Anak lebih bersemangat dalam belajar ketika menggunakan metode } \\
\text { bermain }\end{array}$ & 14 & $70 \%$ & 19 & $95 \%$ \\
\hline 3 & Anak tidak bosan dengan proses belajar mengajar & 11 & $55 \%$ & 20 & $100 \%$ \\
\hline 4 & Anak menyukai cara belajar dengan metode bermain & 13 & $65 \%$ & 18 & $90 \%$ \\
\hline 5 & $\begin{array}{l}\text { Anak lebih memperhatikan Guru Sekolah Minggu ketika proses } \\
\text { belajar }\end{array}$ & 12 & $60 \%$ & 19 & $95 \%$ \\
\hline & \multicolumn{1}{|c|}{ Rerata } & 3.15 & $63 \%$ & 4.8 & $96 \%$ \\
\hline
\end{tabular}

Tabel 1. Data Rekapitulasi Aktivitas Belajar Anak dengan Menggunakan Metode Bermain

Dari data rekapitulasi proses di atas, dapat dideskripsikan sebagai berikut, hasil siklus I diperoleh rerata 3,15 atau sebesar $63 \%$ dengan kriteria keberhasilan cukup. Rerata aktivitas belajar anak di siklus I belum mencapai target keberhasilan tindakan. Sehingga hal ini menjadi landasan untuk pelaksanaan siklus II. Pada siklus II telah menunjukkan tingkat aktivitas belajar anak sebesar $96 \%$ dengan kriteria baik sekali. Dengan demikian dapat disimpulkan, menggunakan metode bermain dalam materi pembelajaran "penciptaan" dapat meningkatkan aktivitas belajar anak. Adapun data rekapitulasi aktivitas belajar anak juga dapat dilihat pada gambar diagram 1 di bawah.

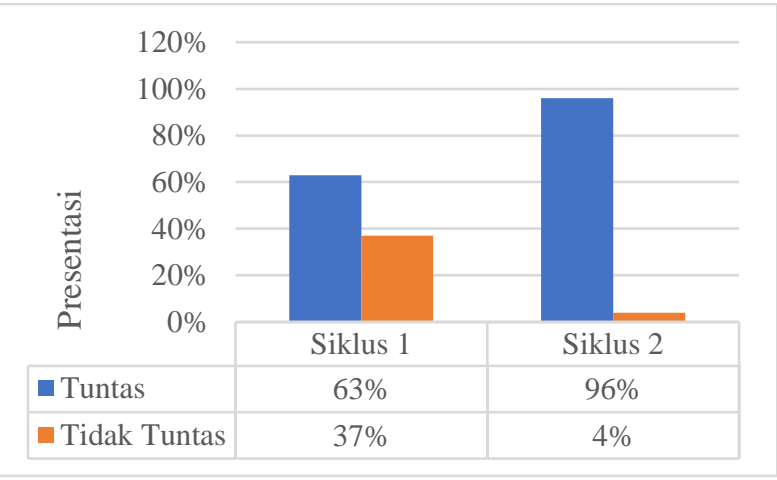

Diagram 1. Aktivitas Belajar

Dari data dalam diagram 1 di atas, peneliti dapat mengatakan ada terjadi peningkatan yang signifikan pada siklus ke-2.

\section{Metode Bermain Meningkatkan Hasil Belajar Anak}

Ada 10 pertanyaan sebagai variable penilaian ketuntasan kemampuan mengingat anak yang digunakan peneliti untuk melihat peningktan hasil belajar anak pada materi "penciptaan manusia". Adapun 10 pertanyaan tersebut sebagai berikut: 1) Siapakah pencipta alam semesta?; 2) Apa penciptaan pada hari keempat?; 3) Apa penciptaan pada hari keenam?; 4) Apa penciptaan pada hari ke satu?; 5) Apa penciptaan pada hari ke lima?; 6) Apa penciptaan pada hari ke dua?; 7) Apa penciptaan pada hari ke tiga?; 8) apa yang dilakukan Allah pada hari ke 7?; 9) sikap apa saja yang harus ditunjukkan sebagai anak-anak Allah?; dan 10) sikap apa yang tidak boleh ditunjukkan sebagai anak-anak Allah?

Saat siklus I mulai diterapkan dalam proses pembelajaran dengan menggunakan metode bermain terhadap 20 orang anak Sekolah Minggu, hasilnya menunjukkan bahwa terdapat 11 orang anak yang dapat dikategorikan tuntas atau 55\%, sedangkan sisanya 9 orang anak atau $45 \%$ belum tuntas sehingga sesuai kriteria dapat dikategorikan cukup. Pada siklus II, setelah diulangi proses tindakan pembelajaran dengan menggunakan metode bermain, maka semua anak dapat menjawab pertanyaan-pertanyaan yang diberikan. Hasil ketuntasan materi penciptaan dapat dilihat pada diagram di bawah. 


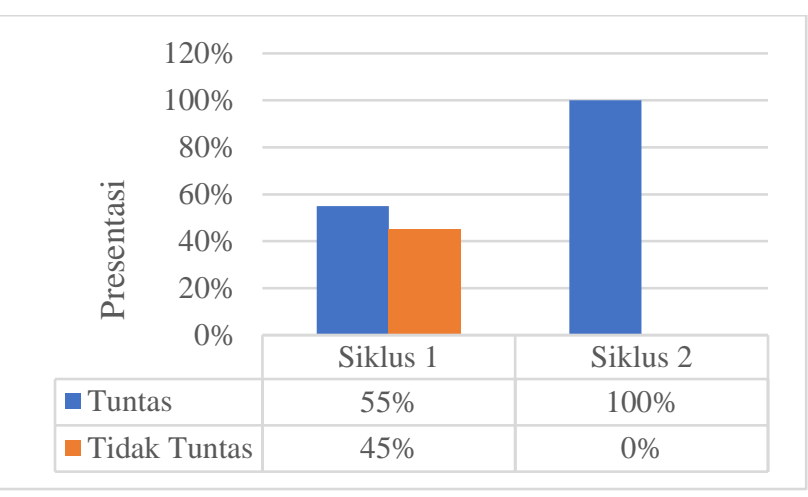

Diagram 2. Ketuntasan Hasil Belajar

Dari data di dalam diagram di atas, maka dapat dikatakan bahwa pada siklus 2 tingkat ketuntasan hasil belajar anak indria mengalami peningkatan yang signifikan.

\section{Pembahasan}

Bermain dianggap serupa kesenangan, sedangkan belajar dianggap seperti pekerjaan. Kebenaran ini melingkupi pendapat bahwa rumah adalah sebuah tempat untuk anak dapat bermain dan sekolah adalah tempat mereka untuk bekerja. Jadi, terkadang bermain menjadi sebuah pandangan yang dinilai kurang baik jika mengaitkannya dengan pembelajaran. Orang tua yang membimbing mereka untuk belajar di rumah tidak diakui; sedangkan guru dijauhkan dari hal-hal yang menyenangkan dalam proses pembelajaran. Sementara itu, permainan dianggap tidak mungkin menjadi sumber pembelajaran yang sejati. Karena kondisi seperti ini, maka banyak hal dalam pendidikan yang sudah salah dimengerti. Bruner dan Donaldson dalam Samples (2002, p. 31) membuktikan bahwa sebagian besar pembelajaran yang paling penting dalam kehidupan didapat dari masa kanakkanak awal yang mana mereka peroleh dari pengalaman "bermain".

Proses pembelajaran di Sekolah Minggu merupakan salah satu tempat dimana anak dapat memperoleh pengalaman belajar untuk lebih mengenal Yesus Kristus selaku Tuhan pencipta alam semesta. Hal yang paling utama dan sangat penting dari seluruh usaha untuk mengembangkan pembelajaran di Sekolah Minggu yaitu mengusahakan agar setiap acaranya selalu menarik. Dengan demikian, Sekolah Minggu menjadi sebuah proses pembelajaran yang bersifat dinamis, kreatif, dan sesuai dengan dunia anak-anak masa kini.

Adalah benar bahwa anak selalu mempelajari sesuatu, tetapi sering kali apa yang mereka pelajari bukanlah apa yang ingin diajarkan oleh Guru Sekolah Minggu. Sementara Guru Sekolah Minggu yang membosankan akan terus berbicara, anak mungkin memutuskan bahwa mereka akan meninggalkan Sekolah Minggu segera setelah orang tua mereka berhenti memaksa mereka untuk datang. Apabila hal demikian terjadi, maka dapat dikatakan bahwa Guru Sekolah Minggu telah gagal dalam mendidik anak untuk mengenal Yesus Kristus. Padahal dalam pengajaran Kristiani, seorang pendidik Kristen "diperintahkan" agar selalu mendidik anak-anak agar dapat mengenal Taurat atau perintah Tuhan, sehingga seandainya satu angkatan berlalu maka angkatan yang lain tidak akan turut berlalu tapi dapat bangkit sebagai generasi penerus (Wenas \& Darmawan, 2017).

Pengajaran di Sekolah Minggu yang benar pada hakikatnya adalah kreatif. Apabila Guru Sekolah Minggu akan mengajar anak tentang firman Allah dan bukannya mengkhotbahkannya kepada mereka, maka harus menghubungkan firman yang tidak berubah itu dengan orang-orang yang selalu berubah. Apabila Guru Sekolah Minggu berusaha membuat firman itu masuk ke dalam anak dengan merangsangnya untuk bertindak atasnya, maka harus menggunakan bagian Alkitab yang memenuhi berbagai kebutuhannya saat ini. Sangat disayangkan apabila seorang pengajar menggunakan beberapa metode yang tidak tepat dengan apa yang diajarkannya. Setiap kali timbul sebuah kebutuhan untuk mengajar, seorang pendidik harus bertanya, "Bagaimanakah saya dapat secara paling baik memenuhi keadaan khusus ini?" dan bukannya bertanya, "Dapatkah saya menemukan sebuah kisah atau papan flanel untuk dipergunakan sekarang?" (Lebar, 1998, p. 297).

Lebar (1998, p. 298) juga menjelaskan bahwa menerapkan firman Allah kepada anak haruslah memberi hasil gagasan-gagasan yang baru. Sama 
seperti seorang pendidik mengharapkan anak untuk menciptakan bentuk-bentuk asli tanpa meniru polapola orang lain, demikianlah mereka harus secara terus-menerus menggunakan kombinasi-kombinasi baru dari berbagai metode, seperti: menggambar, contoh-contoh, ilustrasi-ilustrasi mengenai prinsipprinsip, poster-poster, peta-peta, tulisan prosa dan puisi yang kreatif, diskusi, memperagakan, lakon-lakon pendek yang lucu, debat, laporan-laporan, menggubah musik, adaptasi musik, permainan-permainan, ujian-ujian, wawancara-wawancara, riset, perjalananperjalanan, pengamatan-pengamatan, pengumpulanpengumpulan, batas-batas waktu, perencanaan ibadah, membaca dengan nyaring, dll.

Lebar (1998, p. 303) mengatakan bahwa, "anak-anak itu penuh dengan kejutan sehingga pendidik haruslah selalu siap untuk mengganti cara mengajarnya secara fleksibel ke arah sasaran-sasarannya”. Berdasarkan hal ini, seorang pengajar harus selalu siap untuk menggunakan berbagai metode/cara sesuai dengan kebutuhan anak. Karena, pertumbuhan anak ditentukan bukan oleh apa yang mereka dengar tetapi juga yang dilakukan.

Metode bermain merupakan metode dipakai peneliti dalam proses pembelajaran di Sekolah Minggu. Metode bermain adalah pembelajaran yang dirancang untuk membangun aktivitas belajar anak indria. Metode ini juga dipakai untuk menyesuaikan kondisi psikologi anak yang mana anak pada usia ini lebih menyukai belajar sambil bermain sehingga membuat anak semakin cerdas dan lebih memahami materi.

Proses penelitian ini dilakukan pada Sekolah Minggu Sektor Getsemani Jemaat GPM Seri, Ambon-Maluku. Peneliti melakukan penelitian kepada 20 anak SM dengan memakai materi "Penciptaan" untuk kedua siklus. Sekilas jika dilihat, materi "penciptaan" merupakan salah satu materi yang mudah. Tetapi, tidak semua anak Sekolah Minggu mengerti dengan benar tentang kisah penciptaan (Lauw, 2014). Bahkan, ada beberapa anak Sekolah Minggu di jenjang yang lebih besar, ketika ditanya bagaimana proses penciptaan di Alkitab, mereka belum bisa mengurutkannya dengan baik. Hal ini berarti ketika mereka berada di jenjang yang lebih kecil, mereka tidak diajarkan dengan baik mengenai proses penciptaan yang ada dalam Alkitab. Untuk itulah, peneliti merubah metode atau cara mengajar dari Guru Sekolah Minggu, sehingga anak dapat lebih memahami tentang kisah penciptaan.

Pada dasarnya kompleksitas materi pada kedua siklus sama, demikian juga dengan media yang dipakai dalam pelaksanaan pembelajaran. Jadi, secara substansial karena kondisi materi yang sama pada kedua siklus maka aktivitas dan hasil belajar anak menjadi meningkat, tetapi dengan peningkatan perlakuan pada kegiatan pembelajaran sudah pasti mempunyai dampak pada peningkatan aktivitas dan hasil belajar anak. Kondisi ini didukung beberapa penelitian sebelumnya yang dilakukan oleh Rohmah (2016); Afandi (2015); dan Ayu (2016).

Penelitian yang dilakukan Rohmah (2016) di SD Kelas 5 dengan menggunakan metode bermain peran dapat meningkatkan aktivitas dan hasil belajar anak. Demikian juga penelitian oleh Afandi (2015), ia mengembangkan media pembelajaran permainan ular tangga untuk meningkatkan motivasi belajar dan hasil belajar IPS SD dengan pokok bahasan jenisjenis pekerjaan. Dari proses pengembangan media pembelajarannya, dinyatakan valid oleh validator dan hasil implementasi media pembelajarannya dapat meningkatkan motivasi serta hasil belajar siswa kelas 3 SD. Adapun penelitian yang dilakukan Ayu (2016) di TK Taqifa Bangkinang untuk meningkatkan kemampuan kognitif dalam kegiatan "mengenal lambang bilangan 1-10" dengan metode bermain kartu angka pada anak usia 4-5 tahun mempunyai dampak yang positif. Kemampuan kogntif anak menjadi meningkat sebesar $87 \%$ dari $58 \%$. Sedangkan aktivitas anak dari $73 \%$ menjadi meningkat sebesar $90 \%$.

Latif dkk (2013, p. 78) menyatakan bahwa sewaktu anak bermain, mereka dapat bereksplorasi dan bereksperimen mengenai dunia sekitarnya dengan tujuan agar dapat membangun pengetahuannya (self-knowledge). Pernyataan ini mendukung teori bermain dari Vigotsky dalam Latif (2013, p. 79) yaitu bermain merupakan cara berpikir anak dan caranya 
untuk mengatasi sebuah permasalahan. Zaini (2015) dalam artikelnya mengatakan bahwa bermain merupakan salah satu pendekatan dalam melaksanakan pembelajaran bagi anak usia dini. Belajar sambil bermain dapat membuat anak menjadi senang dan terhibur.

Dari beberapa penelitian terdahulu tersebut, yang menjadi kebaharuan dalam penelitian ini yaitu peneliti melakukan penelitian terhadap anak sekolah minggu yang berusia 4-6 tahun dengan memakai materi "Penciptaan". Dari hasil penelitian yang telah dilakukan, dapat dibuktikan bahwa metode bermain mempunyai kontribusi yang signifikan dalam proses pembelajaran. Sehingga, dalam proses penelitian, peneliti mendapat dua temuan, yaitu: (1) Peningkatan aktivitas belajar dengan metode bermain; dan yang ke (2) Metode bermain meningkatkan hasil belajar menjadi pendukung dalam penelitian ini. Kedua temuan penelitian ini dibahas dalam point di bawah ini.

\section{Peningkatkan Aktivitas Belajar Anak dengan Menggunakan Metode Bermain}

Berdasarkan hasil penelitian, ditemukan bahwa kontribusi metode bermain dapat meningkatkan aktivitas belajar anak. Hal ini didukung dari pernyataan Utami dkk (2013), dengan menerapkan metode bermain dapat meningkatkan aktivitas belajar matematika anak kelas IV SD.

Berdasarkan temuan, kontribusi metode bermain terhadap aktivitas belajar dapat dinyatakan pada siklus I rerata yang diperoleh pada hasil observasi sebesar $63 \%$ dan ketika melakukan perbaikan tindakan pada siklus II, maka hasil observasi menunjukkan rerata sebesar $96 \%$. Artinya, metode bermain memberikan kontribusi secara signifikan terhadap peningkatan aktivitas belajar anak.

Pelaksanaan proses pembelajaran di Sekolah Minggu dilakukan dengan tiga tahapan yaitu: kegiatan awal, kegiatan inti, dan kegiatan akhir. Yang pertama, pada kegiatan awal yang dilakukan peneliti yaitu menyambut anak datang di Sekolah Minggu dan secara langsung mengatur tempat duduk anak dalam posisi lingkaran. Setelah anak-anak sudah berkumpul semua, peneliti mulai membuka proses pembelajaran dengan menyanyi lagu "Matahari bersinar terang", sesudah itu peneliti membuka proses pembelajaran dengan doa. Kegiatan inti dimulai dengan berdoa untuk membaca Alkitab dan peneliti membacakan Alkitab dari Kejadian 1:31. Setelah selesai membaca Alkitab, peneliti mulai menjelaskan proses pembelajaran dengan menggunakan media ular tangga yang telah disediakan. Selesai menjelaskan materi itu, peneliti membagi anak ke dalam 4 kelompok dan mengajak anak-anak untuk bermain ular tangga bersama-sama agar anak dapat mengingat materi yang telah dipelajari. Dalam media ular tangga yang digunakan ini, ada 15 kotak yang terdiri dari gambargambar penciptaan; Tuhan Allah selaku pencipta; hal-hal yang harus di buat dan tidak boleh dibuat sebagai anak Tuhan. Media ular tangga ini dibuat dan dicetak dalam ukuran baliho $3 \times 2$ meter sehingga anak bisa langsung bermain di dalam media tersebut. Seperti yang diketahui, permainan ular tangga membutuhkan pion dan dadu. Sehingga dalam proses penelitian ini, anak sebagai pion-pionnya dan pengasuh yang akan melemparkan dadu. Tujuan kegiatan pembelajaran ini agar anak dapat mengetahui dan memahami materi "penciptaan alam semesta" sebagai salah satu materi mendasar yang sangat penting diketahui anak pada usia dini. Tahapan terakhir dari proses pembelajaran ini yaitu anak kembali di evaluasi dengan memberikan beberapa pertanyaan yang telah disiapkan. Setelah itu, peneliti menutup proses pembelajaran.

\section{Metode Bermain Meningkatkan Hasil Belajar}

Dari hasil penelitian dapat dibuktikan adanya peningkatan hasil belajar anak pada materi penciptaan dengan menggunakan metode bermain. Pernyataan ini didukung dengan penelitian yang dilakukan oleh Tanjung dan Nababan (2018), mereka menyatakan bahwa penggunaan metode bermain terhadap hasil belajar matematika siswa kelas 3 SD materi pokok pecahan terdapat pengaruh yang signifikan.

Besarnya kontribusi hasil belajar yang diberikan dalam penelitian ini dapat dilihat pada ke- 
tuntasan anak dalam menjawab pertanyaan-pertanyaan yang diberikan. Ada 11 anak Sekolah Minggu yang tuntas dalam proses pelaksanaan tindakan pada siklus I sedangkan 9 anak yang lain belum tuntas. Hasilnya membuktikan bahwa ada anak yang belum memahami materi penciptaan. Hal ini berpengaruh dalam penerapan metode bermain pada siklus I dimana pada pencapaiannya belum maksimal. Hasil dari persentase hasil belajar pada siklus 1 diperoleh 55\% dengan kategori kriteria cukup.

Pencapaian hasil ini belum maksimal optimal dikarenakan: 1) anak belum terlalu memahami proses pembelajaran yang dilaksanakan; 2) anak masih belum teratur dalam proses bermain; 3) anak masih menyesuaikan pengenalan dengan gambar-gambar yang ada; dan 4) Guru Sekolah Minggu yang membantu dalam proses penelitian ini pun masih belum memahami prosesnya. Kelemahan inilah yang menjadi dasar untuk melakukan proses perbaikan dan penyempurnaan pada siklus II. Pada sisi lain, ada juga kemajuan pada siklus I, yaitu: 1) keinginan anak untuk berproses dalam pembelajaran, hal ini dapat terlihat pada anak-anak yang bersemangat dalam proses bermain sambil belajar tersebut; dan 2) keinginan anak untuk menjawab pertanyaan yang diberikan peneliti dan Guru Sekolah Minggu, hal ini dapat terlihat pada saat peneliti maupun Guru Sekolah Minggu yang mendampingi memberikan pertanyaan, anak-anak langsung bersemangat menjawabnya walaupun masih

Siklus II dilakukan berdasarkan hasil observasi dan refleksi pada siklus I. Siklus ini dibuat untuk mengatasi beberapa kelemahan yang dialami pada siklus I agar proses pembelajarannya jauh lebih baik. Proses pembelajaran yang dilakukan tidak jauh berbeda dengan siklus I. Setelah melaksanakan tindakan dengan metode bermain, hasil belajar anak mengalami peningkatan. Ke-9 anak yang pada siklus I besalah dalam menjawab.

lum dapat menjawab pertanyaan-pertanyaan dengan benar, sudah dapat menjawab dengan baik dan benar. Begitupun dengan ke-11 anak yang sebelumnya sudah tuntas dalam menjawab pertanyaan di siklus I, mereka masih tetap bisa mempertahankan hasilnya. Keadaan ini menyatakan bahwa metode bermain sangat efektif dalam meningkatkan hasil belajar anak.

\section{KESIMPULAN}

Berdasarkan hasil penelitian serta pembahasan, penelitian tindakaan kelas yang dilakukan secara kolaboratif antara peneliti dengan Guru Sekolah Minggu di Jenjang Indria, dapat disimpulkan sebagai berikut: Pertama, peningkatan aktivitas belajar dengan metode bermain pada jenjang Indria dilakukan dalam dua siklus dengan memakai materi penciptaan. Proses pembelajaran di Sekolah Minggu dilakukan dengan tiga tahapan yaitu: kegiatan awal, kegiatan inti, dan kegiatan akhir. Dari data penelitian yang diperoleh pada tabel skor aktivitas belajar, skor pelaksanaan siklus I diperoleh rerata $63 \%$ dengan kriteria keberhasilan cukup. Siklus penelitian ini kemudian dilakukan kembali pada siklus II dikarenakan belum memenuhi target capaian keberhasilan. Hasil pengulangan di siklus II rerata skor yang dicapai sebesar 96\% atau kriteria baik sekali. Kedua, setelah diterapkan proses pembelajaran di Sekolah Minggu dengan menggunakan metode bermain, hasil belajar menunjukkan ada peningkatan. Hal ini terlihat pada peningkatan presentase dalam diagram 2 (Ketuntasan Hasil Belajar). Saat siklus I diterapkan, presentase anak yang tuntas sebanyak 55\% sedangkan $45 \%$ nya belum tuntas. Ketika diulangi kembali di siklus II, presentasi anak yang tuntas mencapai $100 \%$ atau semuanya berhasil menjawab pertanyaan-pertanyaan yang diberikan. Diharapkan hasil temuan ini menjadi rujukan bagi setiap guru Sekolah Minggu dalam pelaksanaan pembelajaran di Sekolah Minggu.

\section{DAFTAR RUJUKAN}

Afandi, R. (2015). Pengembangan Media Pembelajaran Permainan Ular Tangga Untuk Meningkatkan Motivasi Belajar Siswa dan
Hasil Belajar IPS di Sekolah Dasar. JINoP (Jurnal Inovasi Pembelajaran), 1(1), 77-89. https://doi.org/10.22219/jinop.v1i1.2450 
Ayu, C. (2016). Meningkatkan Kemampuan Kognitif Anak dalam Kegiatan Membilang dengan Metode Bermain Media Kartu Angka pada Anak Usia 4-5 Tahun di TK Taqifa Bangkinang. Jurnal Obsesi: Jurnal Pendidikan Anak Usia Dini, 2(2), 161-172172. https://doi.org/10.31004/obsesi.v2i2.43

Bayoe, Y. V., Kouwagam, M. L., \& Tanyit, P. (2019). Metode Pembelajaran Melalui Film Superbook dan Minat Belajar Firman Tuhan Pada Anak Usia 6-8 Tahun. Jurnal Jaffray, 17(1), 141. https://doi.org/10.25278/jj71.v17i1.327

Benny A. Pribadi. (2009). Model Desain Sistem Pembelajaran. Jakarta: PT Dian Rakyat.

Darmawan, I. P. A., \& Kristanti, D. (2020). Penerapan Model Pembelajaran Picture and Picture dalam Pembelajaran di Sekolah Minggu. REGULA FIDEI: Jurnal Pendidikan Agama Kristen, 5(1), 1-12. https://doi.org/10.33541/regula fidei.v5i1.38

Darmawan, I. P. A., \& Priskila, K. (2020). Penerapan Storytelling Dalam Menceritakan Kisah Alkitab Pada Anak Sekolah Minggu. KURIOS (Jurnal Teologi Dan Pendidikan Agama Kristen), 6(1), 35-46.

Djadi, J. (2007). Metode Pastoral Bagi Anak Sekolah Minggu. Jurnal Jaffray, 5(1), 1-6. https://doi.org/10.25278/jj71.v5i1.120

Hanifah, N. (2014). Memahami Penelitian Tindakan Kelas: Teori dan Aplikasinya. UPI Press.

Ibda, F. (2015). Perkembangan Kognitif: Teori Jean Piaget. Intelektualita, 3(1). Retrieved from https://www.jurnal.arraniry.ac.id/index.php/intel/article/view/197

Indrawati, R. M. (2013). Peningkatan Aktivitas Dan Hasil Belajar Materi Peristiwa Sekitar Proklamasi Melalui Bermain Peran. Journal of Elementary Education, 2(1). Retrieved from

https://journal.unnes.ac.id/sju/index.php/jee/ article/view/2068
J. E. Rahael. (2013). Penggunaan Metode Mengajar yang Kreatif (Studi di SMTPI Jenjang Remaja Jemaat GPM Rumahtiga). IAKN Ambon

Kristiono, T., \& Perdana, D. P. (2019). Hambatan Guru dan Pelayanan Sekolah Minggu di Gereja Kristen Jawa Jebres Surakarta. JURNAL TEOLOGI GRACIA DEO, I(2), 90-100.

Latif, M., Zukhairina, Zubaidah Rita, \& Afandi Muhammad. (2013). Orientasi Baru Pendidikan Anak usia dini: Teori dan aplikasi. Jakarta: Kencana.

Lauw, A. (2014). Motion Comic Kisah Penciptaan Untuk Anak Sekolah Minggu. CALYPTRA, 3(1), 1-6.

Lebar, L. E. (1998). Education that is Christian. David C Cook.

Lie, P. (2009). Mereformasi Sekolah Minggu. Yogyakarta: Andi.

Luhulima, D. A., Degeng, N. S., \& Ulfa, S. (2018). Pengembangan Video Pembelajaran Karakter Mengampuni Berbasis Animasi Untuk Anak Sekolah Minggu. JINOTEP (Jurnal Inovasi Dan Teknologi Pembelajaran): Kajian Dan Riset Dalam Teknologi Pembelajaran, 3(2), 110-120. https://doi.org/10.17977/um031v3i22017p1 10

Mamangkey, J., Sinsuw, A., Karouw, S., \& Tuturoong, N. (2013). Aplikasi E-Visual Aid Sekolah Minggu Berbasis Android. Jurnal Teknik Informatika, 2(2). https://doi.org/10.35793/jti.2.2.2013.2113

Panuntun, D. F., Tanduklangi, R., Adeng, M., \& Randalele, C. E. (2019). Model Ibadah Sekolah Minggu Kreatif-Interaktif bagi Generasi Alfa di Gereja Toraja. BIA': Jurnal Teologi dan Pendidikan Kristen Kontekstual, 2(2), 193-208. https://doi.org/10.34307/b.v2i2.113

Riniwati, R. (2020). Pembinaan Guru Sekolah Minggu Untuk Mengajarkan Konsep 
Keselamatan Pada Anak. Evangelikal: Jurnal Teologi Injili dan Pembinaan Warga Jemaat, 4(2),

185. https://doi.org/10.46445/ejti.v4i2.247

Rohmah, Z. N. (2016). Penerapan Metode Bermain Peran Untuk Meningkatkan Aktivitas dan Hasil Belajar Siswa Kelas V Pada Mata Pelajaran IPS Pokok Bahasan Jenis-Jenis Usaha Ekonomi Di SDN Ngadiluwih 02 Kediri (Skripsi, Universitas Jember). Universitas Jember, Jember. Retrieved from http://repository.unej.ac.id/handle/12345678 9/73426

Samples, B. (2002). Revolusi Belajar untuk Anak: Panduan Belajar Sambil Bermain untuk Membuka Pikiran Anak-anak Anda (R. Astuti, Trans.). Bandung: Kaifa.

Sudono, A. (2000). Sumber Belajar dan Alat Permainan untuk Pendidikan Anak Usia Dini. Jakarta: Grasindo.

Tanjung, H. S., \& Nababan, S. A. (2018). Pengaruh Penggunaan Metode Pembelajaran Bermain Terhadap Hasil Belajar Matematika Siswa Materi Pokok Pecahan Di Kelas III SD Negeri 200407 Hutapadang. Bina Gogik:
Jurnal Ilmiah Pendidikan Guru Sekolah Dasar, 3(1). Retrieved from https://ejournal.stkipbbm.ac.id/index.php/pg sd/article/view/26

Tinggi, R. (2010). Mengajarkan Injil Kepada Anak Usia Empat Sampai Lima Tahun. Jurnal Amanat Agung, 6(1), 71-86.

Utami, P. W., Muncarno, \& Sowiyah. (2013). Penerapan Metode Permainan Untuk Meningkatkan Aktivitas Dan Hasil Belajar Matematika Kelas IV. JURNAL SKRIPSI. Retrieved from https://adoc.pub/penerapanmetode-permainan-untuk-meningkatkanaktivitas-dan-.html

Wenas, M. L., \& Darmawan, I. P. A. (2017). Signifikansi Pendidikan Anak Dalam Perspektif Alkitab. Evangelikal: Jurnal Teologi Injili dan Pembinaan Warga Jemaat, 1(2), 118 https://doi.org/10.46445/ejti.v1i2.69

Zaini, A. (2015). Bermain sebagai Metode Pembelajaran bagi Anak Usia Dini. ThufuLA: Jurnal Inovasi Pendidikan Guru Raudhatul Athfal, $3(1)$, $118-134$. https://doi.org/10.21043/thufula.v3i1.4656 